\title{
Rodents of the eastern and western slopes of the Tropical Andes: phylogenetic and taxonomic insights using DNA barcodes
}

\author{
C. Miguel Pinto ${ }^{1 *}$, Reed Ojala-Barbour ${ }^{1,2}$, Jorge Brito ${ }^{1,3}$, Angélica Menchaca ${ }^{4}$, André L. G. Carvalho ${ }^{5}$, Marcelo \\ Weksler ${ }^{6,7}$, George Amato ${ }^{8}$, and Thomas E. Lee, JR. ${ }^{9}$ \\ ${ }^{1}$ Instituto de Ciencias Biológicas, Escuela Politécnica Nacional, Av. Ladrón de Guevara E11-253. Casilla: 17-01-2759. Quito, Ecuador. \\ Email: miguel.pinto@epn.edu.ec (CMP), jorgeyakuma@yahoo.es (JB). \\ ${ }^{2}$ Washington Department of Fish and Wildlife, Headquarters, 1111 Washington St. SE, WA 98501, Olympia. Washington, U. S. A. Email: \\ reed.ojala.barbour@fulbrightmail.org (ROB). \\ ${ }^{3}$ Museo Ecuatoriano de Ciencias Naturales del Instituto Nacional de Biodiversidad, División de Mastozoología. Calle Rumipamba 341 \\ y Av. de los Shyris. Casilla: 17-07-8976. Quito, Ecuador. \\ ${ }^{4}$ School of Biological Sciences, University of Bristol, 24 Tyndall Ave, Bristol BS8 1TH, United Kingdom. Email: am14886@bristol.ac.uk \\ (AM). \\ ${ }^{5}$ Laboratório de Herpetologia, Departamento de Zoologia, Instituto de Biociências, Universidade de São Paulo (USP), Rua do Matão, \\ Travessa 14, Número 101 05508-090, Cidade Universitária São Paulo Brazil. Email: andreluizherpeto@gmail.com (ALGC). \\ ${ }^{6}$ Laboratório de Ecoepidemiologia da Doença de Chagas, Instituto Oswaldo Cruz, Fiocruz, Avenida Brasil 4365, 21045-900. Rio de \\ Janeiro, Brazil. Email: marcelo.weksler@gmail.com (MW) \\ ${ }^{7}$ Departamento de Vertebrados, Museu Nacional, Universidade Federal do Rio de Janeiro, Quinta da Boa Vista, São Cristóvão, 20940- \\ 040. Rio de Janeiro, Brazil \\ ${ }^{8}$ Sackler Institute for Comparative Genomics, American Museum of Natural History. Central Park West @ 79 ${ }^{\text {th }}$ St. New York10024. New \\ York, U. S. A. Email: gamato@amnh.org (GA). \\ ${ }^{9}$ Department of Biology, Box 27868, Abilene Christian University, 1600 Campus Court, Abilene 79699-27868. Texas, U. S. A. Email: \\ leet@acu.edu (TEL) \\ *Corresponding author
}

The Andes Mountains particularly the forests along the mid-elevations of their eastern and western slopes, are a hotspot of biodiversity (high numbers of species and endemics). Among mammals, rodents are a priority group for study in the Tropical Andes given their high diversity and often relatively small geographic ranges. Here, we use DNA barcoding as a tool to help in the identification, and preliminary analysis of the phylogenetic relationships, of rodents from two natural reserves: Otonga, a private forest reserve, located on the western slopes, and Sangay National Park, located on the eastern slopes of the Ecuadorian Andes. We sequenced 657 bp of the mitochondrial Cytochrome Oxidase I (COI) gene for 201 tissue samples of sigmodontine and echimyid rodents collected primarily in Otonga and Sangay. We conducted phylogenetic analyses using maximum-likelihood and Poisson tree processes (PTP) species delimitation analyses. Three sets of data were analyzed: 1) our newly generated sequences, 2) our Mesomys sequence plus DNA sequences of Echimyidae available in GenBank, and 3) all of our sequences (all Sigmodontinae and one Echimyidae) together with relevant DNA sequences of Sigmodontinae available in GenBank. Our samples consisted of 24 species; the molecular data indicated that only one species-Microryzomys minutus - was shared between both eastern and western localities. Contrary to the currently recognized distributions of Akodon mollis and Chilomys instans, our species delimitation analysis suggests that these species are not shared between Otonga and Sangay, and may actually represent two species each. The sample of Mesomys from the eastern slopes of the Andes differs minimally from that from the lowlands of the Ecuadorian Amazon, suggesting that both populations would correspond to the same species, Mesomys hispidus. Both Mindomys hammondi and an undescribed Mindomys from Otonga do not form a reciprocally monophyletic group with relation to Nephelomys. The Nephelomys of Sangay might correspond to two different species. The eastern and western slopes of the Tropical Andes harbor different species of rodents, with only one of our study species shared between both localities, implying that other cases of shared species between the eastern and the western slopes of the Andes need further assessment. Several lineages represented in our sample may require formal taxonomic description, highlighting the need for further systematic research. The new genetic data generated in our study could speed taxonomic discovery in the Andes and help to illuminate interesting evolutionary patterns, such as the radiation of Thomasomys.

Los Andes particularmente los bosques de las elevaciones medias de las estribaciones occidentales y orientales, son un punto caliente de biodiversidad (alto número de especies y de endemismo). Entre los mamíferos andinos, los roedores son un grupo prioritario a ser estudiado dada su alta biodiversidad y sus rangos de distribución que por lo general son pequeños. En esta contribución, usamos códigos de barras de ADN como una herramienta para la identificación y generación de hipótesis filogenéticas preliminares de los roedores colectados principalmente en dos reservas naturales: Otonga, ubicada en las estribaciones occidentales, y Sangay, localizada en las estribaciones orientales de los Andes ecuatorianos. Secuenciamos 657 pares de base del gen mitocondrial Citocromo Oxidasa I (COI) en 201 muestras de tejido de roedores sigmodontinos y echimyidos colectados principalmente en Otonga y Sangay. Hicimos análisis filogenéticos usando máxima verosimilitud, y análisis de delimitación de especies mediante el proceso de árboles de Poisson (PTP). Tres grupos de datos fueron analizados: 1) todas nuestras nuevas secuencias generadas, 2) nuestra secuencia de Mesomys más las secuencias de ADN de Echimiydae disponibles en GenBank, y 3 ) todas nuestras secuencias (mayoritariamente Sigmodontinae) junto con secuencias de ADN de Sigmodontinae disponibles en GenBank. Nuestra muestra contiene 24 especies; los datos moleculares demuestran que solo una especie-Microryzomys minutus_es compartida entre ambas localidades del este y oeste. Mientras que nuestro análisis de delimitación de especies sugiere que Akodon mollis y Chilomys instans no son compartidas entre Otonga y Sangay, y representan dos especies cada una. La muestra de Mesomys de la vertiente oriental de los Andes es mínimamente diferente de secuencias de las tierras bajas de la Amazonia ecuatoriana; recomendando que ambas poblaciones podrían corresponder a la misma especie, Mesomys hispidus. Mindomys hammondi y una especie no descrita de Mindomys de Otonga no forman un grupo monofilético en relación a Nephelomys. 
Los Nephelomys de Sangay corresponderían a dos especies diferentes. Las vertientes occidental y oriental de los Andes tropicales albergan especies diferentes de roedores, con una sola especie compartida entre ambas indicando que otros casos de especies compartidas entre el este y occidente necesitan ser investigadas con mayor detalle. Múltiples especies de nuestra muestra necesitarían descripción formal, lo que revela que se requiere más investigación sistemática en la región. Los nuevos datos genéticos aquí presentados podrían acelerar los descubrimientos taxonómicos en los Andes y ayudar a explorar patrones volutivos interesantes, como la radiación de los Thomasomys.

Key words: Akodon, Andes, Chilomys, Echimyidae, Ecuador, Microryzomys, Oligoryzomys, Sigmodontinae, species delimitation, Thomasomys.

(c) 2018 Asociación Mexicana de Mastozoología, www.mastozoologiamexicana.org

\section{Introduction}

The Andes Mountains encompass diverse environments along their slopes, ranging from lowland forests to glaciercovered peaks at over 6,000 meters above the sea level (masl). These different environments harbor high levels of species diversity and endemism, and together they make the Andean region one of the most important diversity hotspots on the planet (Myers et al. 2000). The Andean rodent fauna is no exception to these environmental trends. Recent analyses have detected several hotspots of rodent diversity along the Andes, such as the eastern slopes in Ecuador and Peru (Prado et al. 2015; Maestri and Patterson 2016).

The systematics of Neotropical rodents is in a phase of rapid update and improvement, triggered especially by active efforts in Latin American countries to train taxonomic specialists (Voss 2009) and by the recent availability of a synthetic treatment of the entire rodent fauna of South America (Patton et al. 2015). However, many systematic relationships remain to be clarified, especially in clades of Andean rodents such as akodontines and thomasomyines, as well as some oryzomyines and echimyids. Such studies have been difficult to perform due to various limitations in past collecting and inventory work (Patterson 2002), and the logistic difficulties of visiting natural history museums in foreign countries to undertake revisionary work. These difficulties are evidenced, for example, in the data gaps for rodent sampling in various areas, such as in middle elevation forests near Papallacta in eastern Ecuador (Voss 2003).

The rodent fauna of the Andean slopes of northwestern South America is rich in species of Thomasomys. It is not uncommon to find large (e. g., T. aureus), medium (e. g., T. silvestris), small (e. g., T. baeops), and very small (e. g., T. cinnameus) species of the genus living in sympatry (Jarrín 2001; Pacheco 2003, 2015; Lee et al. 2011). Other components of the rodent fauna of the Andean forests include oryzomyines such as Microryzomys, Nephelomys, Oreoryzomys, and the enigmatic Mindomys hammondi, which is known from few specimens (Carleton and Musser 1989; Weksler 2006; Weksler et al. 2006).

The usage of molecular markers has been pivotal to accelerate and improve taxonomic work. One common approach has been the use of DNA barcodes-sequences of the mitochondrial gene $\mathrm{COI}$ - which have been applied successfully for facilitating identifications of specimens in Neotropical faunal surveys (Clare et al. 2007; Borisenko et al. 2008); however, this approach has not been used exhaustively with Andean mammals. Here, we use DNA barcoding as evidence to identify and conduct preliminary phylogenetic analysis of rodents from two natural reserves: Otonga, located in the western slopes of the Andes (cis-Andean), and Sangay National Park, located in the eastern slopes of the Andes (trans-Andean). Also, we explore whether populations shared between the eastern and western slopes of the Andes are likely to be conspecific, or alternately whether they represent divergent lineages that may not be recognized under current taxonomic classifications.

\section{Materials and Methods}

Sampling. We used selected samples of 21 species of rodents, primarily identified on the basis of morphological characters, collected in two Andean forests: Otonga, a private forest reserve located in the western slopes of the Andes in the province of Cotopaxi in northern Ecuador (Jarrín 2001), and Sangay National Park located in the eastern slopes of the Andes in the provinces of Chimborazo, Morona Santiago and Tungurahua in south-central Ecuador (Armstrong and Macey 1979; Fonseca et al. 2003; Figure 1). Three different field parties collected voucher specimens with tissues during 2006 in Otonga, and during 2010 and 2012 in Sangay. Morphological identifications of all specimens were conducted using specialized taxonomic literature (e. g., Carleton and Musser 1989; Weksler 2006; Patton et al. 2015), and by side-by-side comparisons with voucher specimens from the following collections: Abilene Christian University (ACUNHC) in Abilene, Texas, USA; American Museum of Natural History (AMNH) in New York, New York, USA; Escuela Politécnica Nacional (MEPN) in Quito, Ecuador; Museo Ecuatoriano de Ciencias Naturales (MECN) in Quito, Ecuador; National Museum of Natural History (NMNH) in Washington DC, USA; and Pontificia Universidad Católica del Ecuador (QCAZ) in Quito, Ecuador. Some previous findings of the mammals collected by these parties have been reported elsewhere (Lee et al. 2011; Helgen et al. 2013; OjalaBarbour et al. 2013; Brito and Ojala-Barbour 2014; Brito et al. 2014; Brito et al. 2017). Examined specimens are housed at different mammal collections as indicated in Appendix 1.

Laboratory work. We used the DNeasy kit (Qiagen, Valencia, California, USA), following the manufacturer's protocol, to extract DNA of 201 samples of either liver or muscle from rodents collected in Otonga and Sangay. We performed PCR amplifications with the Illustra puReTaq Ready-To-Go PCR beads (GE Healthcare, Little Chalfont, Buckinghamshire, UK) to amplify a fragment of the mitochondrial COI gene using the "cocktail 2"-an M13-tailed primer cocktail optimized for mammals - with the primer ratios and thermal cycle conditions of Clare et al. (2007). We 


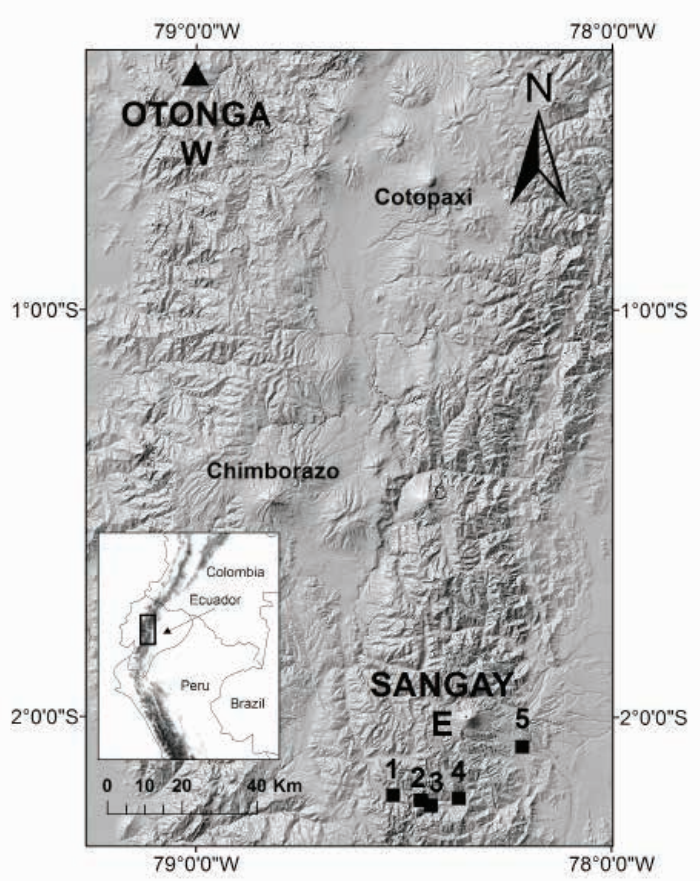

Figure 1. Otonga Reserve and Sangay National Park, localities of the rodent specimens analyzed in this study. Otonga samples were collected by Helgen et al. (2013). For Sangay, points 1 and 2 correspond to localities near the Atillo Lagoon sampled by Lee et al. (2011); and points 3 to 5 correspond to localities sampled by J. Brito and R. OjalaBarbour (Ojala-Barbour et al. 2013; Brito et al. 2014). Chimborazo and Cotopaxi volcanoes are labeled as points of reference. Inset: map of northwestern South America indicating in a black rectangle the expanded map.

cleaned the PCR products with ExoSAP-IT (Affymetrix Inc., Santa Clara, California, USA), and conducted sequencing reactions with the $A B I$ Big Dye chemistry (Applied Biosystems, Inc., Foster City, California, USA), using the primers M13F and M13R (Messing 1983). We sequenced the products on an ABI 3730xI DNA Analyzer automatic sequencer (Applied Biosystems, Inc., Foster City, California, USA). New sequences were deposited in GenBank (accession numbers: MF806172 - MF806372).

Phylogenetic analyses. We constructed three alignments: (A) an alignment containing our 201 newly generated sequences; (B) an alignment including our sample of Mesomys, a COI sequence of Chinchilla lanigera, and 614 sequences of the $\mathrm{CO}$ gene of members of the family Echimyidae (retrieved from the nucleotide database of GenBank searching for "Echimyidae COI"); C) an alignment including our 201 newly generated sequences plus 1,775 sequences of sigmodontinae rodents retrieved from GenBank with the search terms "Sigmodontinae COI". To align the sequences we used the MUSCLE (Edgar 2004) plugin in Geneious Pro v8.1.5 with default parameters. We checked the alignments manually for obvious misplacements, and trimmed all alignments to a length of $657 \mathrm{bp}$.

For each alignment we conducted phylogenetic analyses using maximum likelihood in RAxML v8 (Stamatakis 2014). We used the model GTRGAMMA for alignment Atree A-(Figure 2) and the model GTRCAT for alignments $\mathrm{B}$-tree $\mathrm{B}$-(Figure 3 ) and $\mathrm{C}$-tree $\mathrm{C}$-(Figures 4 to 7 ). For each analysis support values were estimated using 1,000 nonparametric bootstrap pseudo replicates. For analyses $\mathrm{A}$ and $C$ we used as outgroup our sequence of Mesomys, and of Chinchilla lanigera for analysis B. For each RAxML analysis, we started with a complete alignment as described above to obtain the reduced alignment (a matrix without redundant haplotypes); later, we resumed the analysis with the reduced alignment and let it finish.

Species delimitation. We performed species delimitation analyses for the best maximum likelihood trees using the Poisson tree processes (PTP) method in the bPTP web server (Zhang et al. 2013). The PTP method was built as an operational criterion of the Phylogenetic Species Concept (Eldredge and Cracraft 1980). PTP is a fast and accurate species delimitation method that uses as input a non-ultrametric tree; PTP models speciation rates from the number of substitutions in a phylogeny, and expects to find statistically significant differences from intra and inter specific relationships (Zhang et al. 2013). PTP has been successfully applied to mammals and other organism such as trypanosome parasites (Cottontail et al. 2014; Ermakov et al. 2015; Bernal and Pinto 2016), and this method has been found to be more robust than the popular GMYC method that uses time divergences from ultrametric trees which are error prone and computationally expensive to estimate (Zhang et al. 2013; Tang et al. 2014). We ran the PTP analyses for 100,000 MCMC generations for tree $A, 200,000$ MCMC generations for tree $B$, and 400,000 generations for tree C. For all analyses we set the thinning value at 100 , a burn-in of 0.1 , and removed outgroups to improve species delimitation.

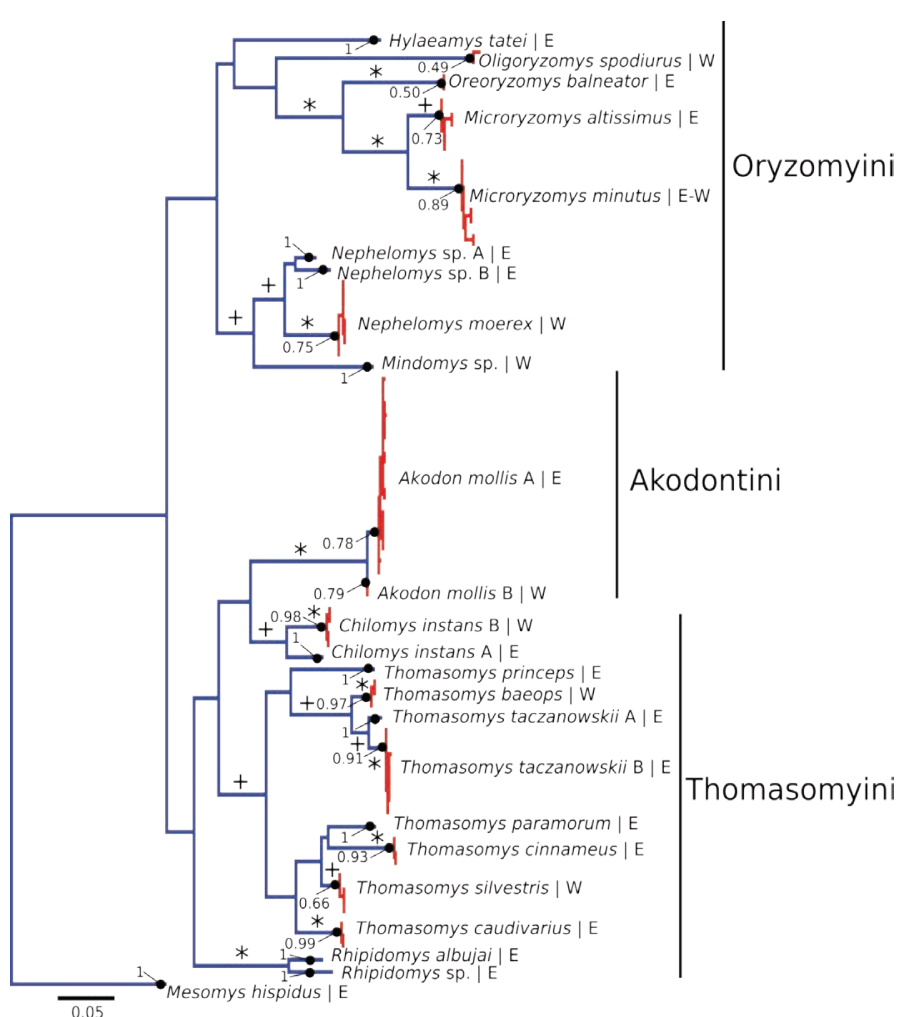

Figure 2. Maximum likelihood gene tree (tree $A$; see text) of unique haplotypes of the COI gene of the rodents collected in Otonga (West, W) and Sangay (East, E). Color of the branches indicates the results of the PTP species delimitation analysis: monophyletic groups in red indicate a single putative species as well as terminal branches in blue. Numbers associated with each putative species are supporting values of the PTP species delimitation; values of 1 indicate the highest possible support. Single plus symbols indicate main branches with moderate ML bootstrap values $\geq 75 \%$, and asterisks indicate main branches with strong ML bootstrap values $\geq 95 \%$. 


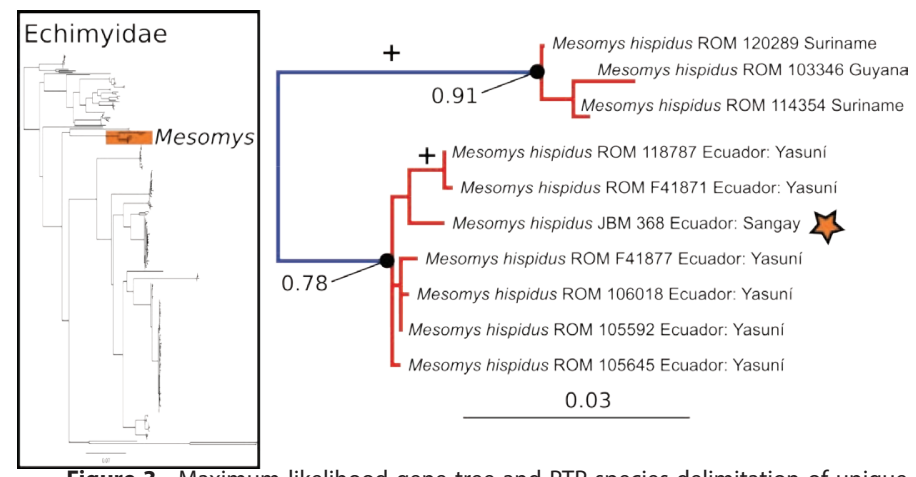

Figure 3. Maximum likelihood gene tree and PTP species delimitation of unique haplotypes of the COI gene of the rodents of the family Echimyidae available in GenBank plus the sample of Mesomys collected at Sangay in the eastern slopes of the Ecuadorian Andes (inset); main figure panel is a zoom-out of tree to depict only the genus Mesomys, showing two putative species within M. hispidus. Colors, symbols and support values correspond to the same as in Figure 2. Names of terminals indicate sample codes and geographic origin of the samples; sequences retrieved from GeneBank keep their original identifications. Star indicates the sample of Mesomys hispidus from Sangay.

\section{Results}

Our maximum likelihood gene tree A (Figure 2) recovered a paraphyletic tribe Thomasomyini (represented in our sample by Thomasomys, Chilomys, and Rhipidomys) relative to Akodon mollis; however, the members of the Oryzomyini were recovered as a monophyletic group (Figure 2). The maximum likelihood species delimitation analysis in PTP of tree A returned 24 candidate species. Even though we expected three shared species between both sides of the Andes (Figure 1), the molecular data supported that only one species-Microryzomys minutus - was shared between both eastern and western localities. In contrast, Akodon mollis, and Chilomys instans show structured variation, with percentage of difference $>1.4 \%$ between both putative species of Akodon and $7 \%$ between the putative species of Chilomys. Also, our species delimitation suggests that Thomasomys taczanowskii is comprised of two putative species, both distributed in the Eastern slopes of the Andes; the divergence between both is $3 \%$ (Figure 2).

The maximum likelihood gene tree of the family Echimyidae - tree B - (Figure 3) contained 281 unique terminals, and the maximum likelihood PTP analysis of species delimitation returned 42 candidate species. The sample of Mesomys from the eastern slopes of the Andes is nested with sequences of Yasuní National Park from the lowlands of the Ecuadorian Amazonia, confirming that both populations likely correspond to the same species (Figure 3).

The COI gene tree of the subfamily Sigmodontinae (tree C; Figures 4 to 7) consisted of 1,020 unique sequences, and the maximum likelihood species delimitation returned 153 candidate species. The genus Oligoryzomys was recovered as polyphyletic. The Otonga samples of Oligoryzomys destructor are sister to a clade of Oligoryzomys species including 6 candidate species within $O$. fulvescens and a sample identified as $O$. nigripes (Figure 4). The genera Mindomys and Nephelomys form a monophyletic group. However, the genus Mindomys ( $M$. hammondi and an undescribed Mindomys from Otonga) was not recovered monophyletic (Figure 5). The specimens of Nephelomys from Sangay National Park might correspond to two different species, with a divergence of $5.6 \%$, and Nephelomys moerex from Otonga is sister to two Nephelomys species from Central America (Figure 5). The genus Hylaeamys was recovered as monophyletic and $H$. tatei was nested well inside the genus, as sister to a clade comprised of 6 candidate species currently identified within $H$. yunganus (Figure 6). Both species of Rhipidomys from Ecuador form a monophyletic group sister to a clade formed by $R$. scandens, R. leucodactylus (2 putative species), and R. nitela (Figure 7).

\section{Discussion}

The DNA barcoding initiative was established as a fast and universal approach to speed the discovery and identification of species (e. g., Hebert et al. 2003; Hebert and Gregory 2005; Harris and Bellino 2013). However, using the mito-

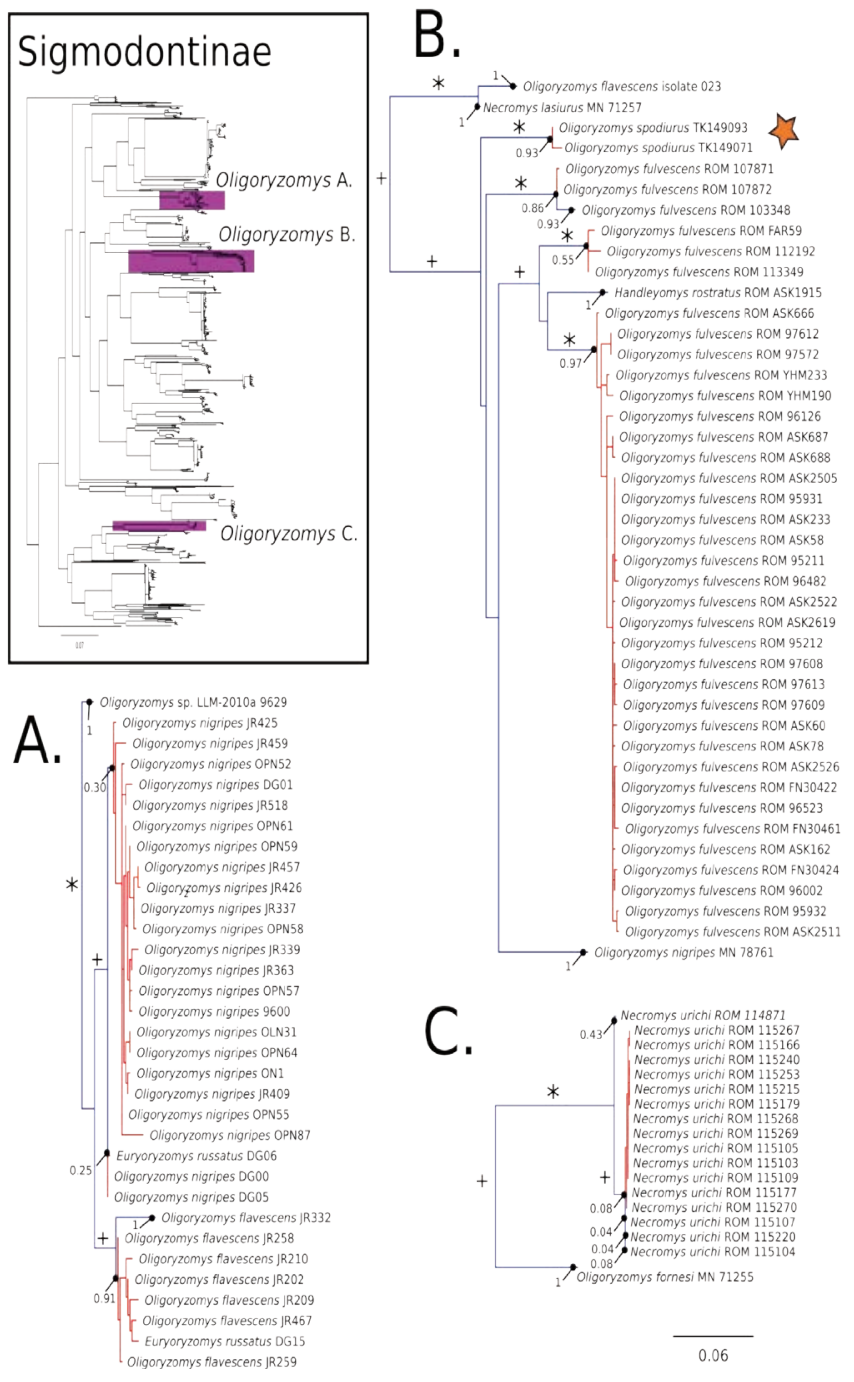

Figure 4. Maximum likelihood gene tree and PTP species delimitation of unique haplotypes of the COI gene of the rodents of the subfamily Sigmodontinae available in GenBank plus our sample (Appendix 1) collected in Otonga Reserve and Sangay National Park (inset). Main figure panels are zoom-outs of the three clades were appear representatives of Oligoryzomys. Colors, symbols and support values correspond to the same as in Figure 2. Names of terminals indicate sample codes; sequences retrieved from GeneBank keep their original identifications. Star indicates the samples of Oligoryzomys spodiurus from Ontonga. Oligoryzomys is depicted as a paraphyletic genus; this is regarded as a spurious result (see text). True Oligoryzomys is depicted in clade B. 

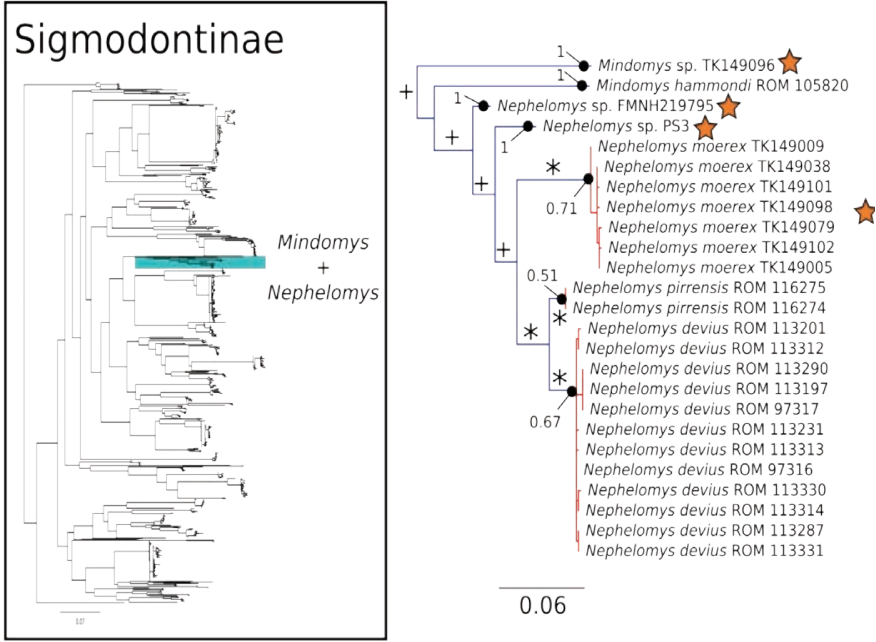

Figure 5. Maximum likelihood gene tree and PTP species delimitation of unique haplotypes of the $\mathrm{COI}$ gene of the rodents of the subfamily Sigmodontinae available in GenBank plus our sample (Appendix 1) collected at Otonga Reserve and Sangay National Park (inset). Main figure panel is a zoom-out of the Mindomys + Nepehelomys clade. Colors, symbols and support values correspond to the same as in Figure 2. Names of terminals indicate sample codes; sequences retrieved from GeneBank originally identified as $N$. albigularis were reclassified as $N$. devius and $N$. pirrensis based on their geographic origins. Stars indicate the species of Mindomys and Nephelomys sequenced for this study.

chondrial COI gene as the marker of choice for mammals has faced resistance from researchers used to working mainly with the CYTB gene; this is shown by the asymmetric number of sequences for the two markers deposited in GenBank (as of December 31 ${ }^{\text {st }}, 2016$ there are 37,101 and 136,965 sequences of the mammalian COI and CYTB genes, respectively). Also it has been argued that CYTB gene performs better in deeper nodes of phylogenies, and it seems more informative for discriminating species (Tobe et al. 2010); however, this stance has faced criticism, as it has been demonstrated that COI gene behaves similarly to CYTB gene (Nicolas et al. 2012), and various studies have successfully made use of COI gene for species identifications (e. g., Clare et al. 2007; Borisenko et al. 2008). Although, we are aware that single locus phylogenies are substandard, and wellaccepted phylogenetic inferences in mammals are increasingly made with larger, even genomic scale datasets (e. g., Meredith et al. 2011; Foley et al. 2016). In this study we found the $\mathrm{COI}$ gene to be a useful marker for species identification; however, more taxa and loci are needed to obtain robust phylogenies of these rodent taxa.

Along the Andes there are three main patterns of allopatric distributions: (1) a latitudinal pattern is evidenced when a pair of sister species are distributed one to the north and the other to the south, e. g., Hippocamelus antisensis (north) vs. H. bisulcus (south), and Nasuella meridensis (north) vs. N. olivacea (south) (Helgen et al. 2009; Pinto et al. 2016); (2) a cross Andean pattern is evidenced when a pair of sister species are distributed with one in the eastern slopes and another in the western slopes of the Andes, e. g., Bassaricyon alleni (east) vs. B. medius (west) (Helgen et al. 2013); and (3) altitudinal pattern is evidenced when one species is in higher elevations and its close relatives are in lower elevations, e. g., Bassaricyon neblina and Dactylomys peruanus vs. the rest of the species in their respective genera (Helgen et al. 2013; Upham et al. 2013). In this work, we highlight further possible examples of the cross
Andean pattern of distributions: of the three species supposedly shared between the eastern and western slopes of the Andes, two (Chilomys instans and Akodon mollis) may represent multiple species. However, suggestion of two species within Akodon mollis in particular should be interpreted with caution; the scant genetic differentiation between the Otonga and Sangay specimens $(<2 \%)$ and the fact that $A$. mollis is a widespread Andean species might suggest that intermediate lineages in the inter-Andean valleys are yet to be found, and we may have only one - not multiple - species level clades (Lee et al. 2011). Further sampling, and the analysis of additional morphological and genetic data will elucidate whether A. mollis is one or multiple species (Alvarado-Serrano et al. 2013). Our results from DNA barcoding provide preliminary views into biodiversity within these lineages which can be explored with other datasets, approaches, and sampling.

As noted, our results indicate that the interpretations of rodent species being widely distributed across both the eastern and western slopes of the tropical Andes should be viewed with certain caution. Of the species that we sampled in our comparisons, only Microryzomys minutus can be considered to indeed occupy both Andean slopes in light of our barcode data. Potentially, this Andean species is well adapted to different environments such as high elevation grasslands (páramos), Andean forests, and inter-Andean valleys. This tolerance to multiple environments would facilitate the colonization of both Andean slopes, but at the same time this may suggest that forest specialists (e. g., Chi-

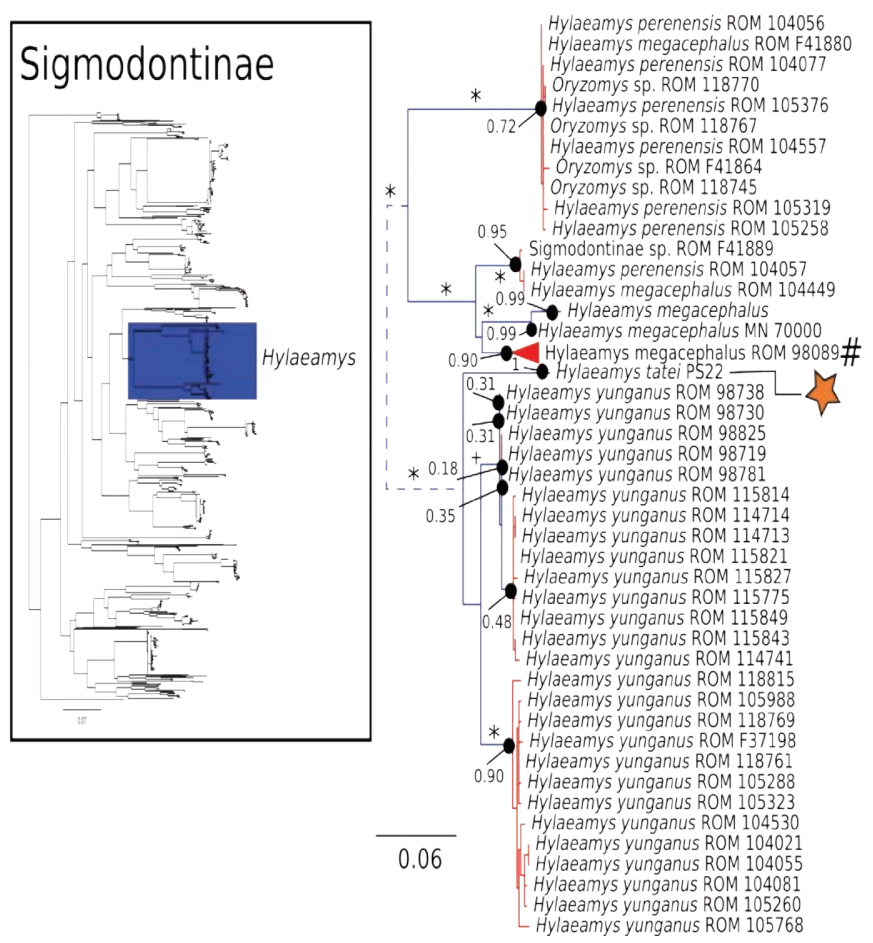

Figure 6. Maximum likelihood gene tree and PTP species delimitation of unique haplotypes of the $\mathrm{COI}$ gene of the rodents of the subfamily Sigmodontinae available in GenBank plus all our samples included in Figure 2 collected in Otonga Reserve and Sangay National Park (inset); main figure panel is a zoom-out of the Hylaeamys clade. Colors, symbols and support values correspond to the same as in Figure 2. Names of terminals indicate sample codes; sequences retrieved from GeneBank keep their original identifications. Star indicates the sample of Hylaemays tatei from Sangay. Pound symbol indicates a very large clade of Hylaeamys megacephalus that was collapsed to obtain a clearer representation of this figure. Doted lines indicate branch lengths were reduced. 


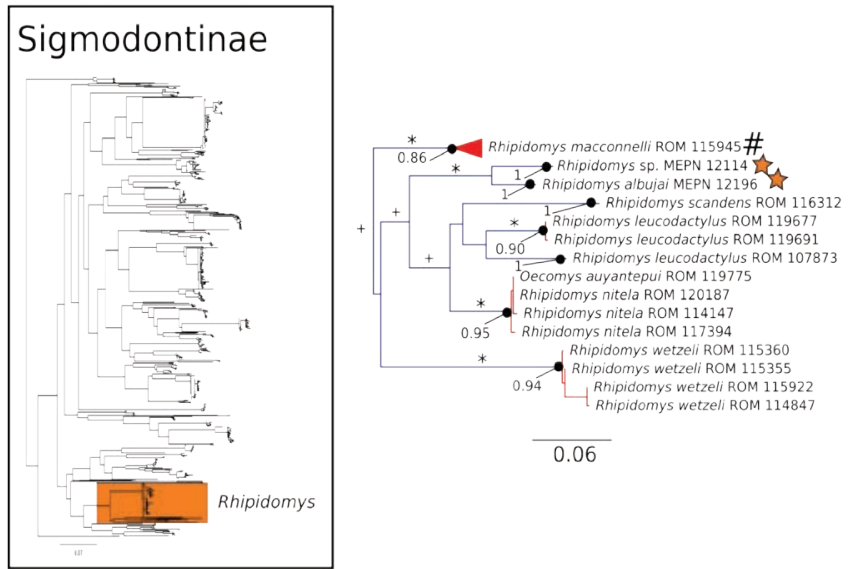

Figure 7. Maximum likelihood gene tree and PTP species delimitation of unique haplotypes of the COI gene of the rodents of the subfamily Sigmodontinae available in GenBank plus all our samples included in Figure 2 collected in Otonga Reserve and Sangay National Park (inset); main figure panel is a zoom-out of the Rhipidomys clade. Colors, symbols and support values correspond to the same as in Figure 2. Names of terminals indicate sample codes; sequences retrieved from GeneBank keep their original identifications. Stars indicate the two species of unnamed Rhipidomys reported in this study. Pound symbol indicates a very large clade of Rhipidomys macconnelli that was collapsed to obtain a clearer representation of this figure.

lomys) would be less likely to colonize both Andean slopes.

Species delimitation methods, such as PTP and GMYC, are useful as an initial approach to delimit species using DNA sequences (Pons et al. 2006; Zhang et al. 2013). While these inferences are useful, there are also several pitfalls associated with these analyses and the results should be taken with caution, particularly when only one method and locus are used (Carstens et al. 2013). In our results, the splitting of Akodon mollis could very well represent a false positive associated with shallow genetic differentiation; however, the deep divergence between both clades within Chilomys instans indicates that the delimitation results might reflect real species-level diversity (Figure 2). In the case of species delimitation of the subfamily Sigmodontinae (Tree C), it is possible that there was an over-splitting of species by the PTP analysis; for example, there was a potential over splitting of Hylaeamys yunganus in multiple species (Figure 6). Further systematic research will clarify the species limits of these taxa.

Following the analyses of González-Ittig et al. (2014) we preliminarily recognize the Oligoryzomys of the western slopes of the Ecuadorian Andes as O. spodiurus; these populations were traditionally regarded as part of the widespread O. destructor (Weksler and Bonvicino 2015). We also recovered Oligoryzomys as paraphyletic, but we propose that this may be due to two artifacts: incorrect identifications of various voucher specimens associated with sequences available in GenBank (sequences of specimen MN71255 [GenBank accession number: KF815407] (Figure 4C) actually belongs to Necromys lasiurus, based on the analysis of CYTB of the same specimen,results not shown); and putative pseudogenes (Numts; Bensasson et al. 2001) in sequences generated by Müller et al. (2013) [GenBank accession numbers: GU938877, GU938878, GU938886GU938890, GU938892-GU938894, GU938898, GU938899, GU938953, GU938969-GU938988] (Figure 4A), based on the position of these sequences in an analyses of a larger data- set of Oligoryzomys barcodes (M. Weksler et al., in prep.). Traditionally, the genus Oligorzomys has been a hard group to study because of the availability of a large number of taxonomic names and various difficulties inherent in assessing patterns of morphological variation. Fortunately, there have been new efforts to generate a more comprehensive understanding of the diversity in the genus (Weksler and Bonvicino 2005, 2015; González-Ittig et al. 2014; Weksler et al. 2017). Our barcode data corroborate the sister relationship of Oreoryzomys, a poorly studied Andean genus, and Microryzomys (Weksler 2006).

Even though our phylogenetic analysis of the $\mathrm{COI}$ gene did not recover the two species of Mindomys as monophyletic (Figure 5), further analysis with the IRBP and CYTB gene do indeed recover these two species as a monophyletic lineage (C. M. Pinto and M. Weksler in prep.), a good example of the marked limitation of DNA barcoding for providing accurate insight into species-level phylogenetics. Mindomys form a monophyletic group with Nephelomys; both of these genera are mostly Andean, with two species of Nephelomys, N. devius and N. pirrensis, distributed in the mountain areas of Central America (Percequillo 2003, 2015). Our barcode data suggest that $N$. moerex of the western slopes of the Andes may be most closely related to Central American species (Figure 5). Without further systematic study we are not yet confident in assigning species names to the two candidate species of the eastern slopes of the Andes; potential names for these candidate species include N. albigularis, N. auriventer, and N. nimbosus (Brito et al. 2015; Percequillo 2015; Tinoco López 2015).

The tribe Thomasomyini was not recovered as monophyletic in our Maximum Likelihood analyses (Figure 2). This result is not surprising for several reasons: 1) Monophyly of this tribe is not strongly supported in studies using additional molecular data - CYTB and IRBP genes - (SalazarBravo et al. 2016). 2) The COI marker is problematic for unveiling deep nodes in phylogenies; a recent example of this limitation is the utility of this marker to in the phylogeny of bats, without using constraints (Amador et al. in press). 3) The taxonomic sampling of the analysis was very limited with only 24 species; it is known that phylogenetic accuracy increases with taxon sampling (Zwickl and Hillis 2002).

Currently, specimens of Thomasomys from Sangay are assigned to T. caudivarius, T. cinnameus, T. paramorum, T. princeps and T. taczanowskii (Lee et al. 2011, 2015). Our phylogenetic analyses show that true T. silvestris, from Otonga, are sister to a clade formed by T. paramorum and T. cinnameus; also the large species T. princeps is closely related to small sized species T. baeops and T. taczanowskii. These relationships differ from previous phylogenetic hypotheses based solely on morphological or CYTB data (Pacheco 2003; Lee et al. 2011, 2015); the single relationship that is constant across phylogenies is the sister relationship of $T$. baeops and T. taczanowskii. Two putative species were recovered within T. taczanowskii (Figure 2); however, it is possible that they correspond to a single species given the scant genetic divergence with the COI gene (3\%). The puzzling pattern showing that large species of Thomasomys do not 
form a clade (Lee et al. 2015) potentially indicates multiple origins of the large body-size phenotype, suggesting that the evolution of body size in Thomasomys is more complex than previously suggested by discrete grouping of species by body-size (Pacheco 2003, 2015). Detailed exploration of the radiation of thomasomyine rodents along the Andes is much needed, and will likely provide exciting results about diversification patterns along the Andes, as have emerged from studies of plants (e. g., Monasterio and Sarmiento 1991; Hughes and Eastwood 2006; Nürk et al. 2013).

The results for Echimyidae show that the analyzed sequences of Mesomys hispidus contain two putative species with divergences in the range of 6.9- 7.2 \% (Figure 3). One of these putative species is distributed in the Guiana Shield, and the other in the western Amazon of Ecuador. These results are in line with the findings of five relatively deep mitochondrial clades within M. hispidus, with mean divergence $4.6 \%$ (Patton et al. 1994, 2000). Also, our results suggest that the Mesomys sample (JBM 368) from the Andes is conspecific with the Mesomys from Yasuní in the western Amazonian lowlands (genetic divergence ranging from 1.2 to $1.4 \%$ ). These results contrast with a previous analysis, in which the sample JBM 368 was assigned as a different species from the lowland samples (Upham et al. 2013). Additional work on the morphology and genetics of M. hispidus will be needed to clarify its taxonomy.

Our results indicate that the alpha taxonomy of the tropical Andean rodents is still not fully resolved, for example with respect to delineation of species in the genera Chilomys and Mindomys. Also, COI sequences that we have obtained for the genera Thomasomys and Chilomys provide the first data from this marker for these genera, and may be useful for onward rodent barcoding efforts and for efforts toward a comprehensive multilocus phylogeny of thomasomyines, which remains an outstanding goal in Neotropical mammalogy (Salazar-Bravo and Yates 2007; Lee et al. 2011, 2015). While acknowledging its limitations, we encourage research teams studying Neotropical rodents to provide DNA barcoding data whenever possible, which may help to speed new species discoveries and taxonomic reviews in a highly diverse order in which many lines of basic taxonomic and inventory research remain open, active, and fruitful.

\section{Acknowledgments}

Fieldwork discussed in our paper was facilitated by a grant from the Texas Tech University Association of Biologists to CMP, a Fulbright United States Student Program grant and a Barbara E. Brown Fund for Mammal Research (FMNH) to RO-B, and grants and funds of Abilene Christian University to TEL. The Sackler Institute for Comparative Genomics at the American Museum of Natural History, and the Smithsonian Institution funded laboratory work. Escuela Politécnica Nacional supported CMP through grants PIMI-14-10 and PII-ICB-03-2017. We thank Roland Kays, Paul Pinto, Elicio Tapia, and Don Wilson for help in the field. We thank Verónica Crespo-Pérez for a helpful revision of this manuscript and providing help with figures. Katherine Moreno helped with the map, and Pablo Moreno helped locating specimens and data. Field expeditions were conducted under legal authorizations of the Ministerio del Ambiente de la República del Ecuador; permit numbers: 020 IC FAU-DNBAPVS/MA, 02-2010-FAU-DPAP-MA, 001-12-PMVSFAU-DNB/MA,13-2011-INVESTIGACION-B-DPMS/MAE, and MAE-DNA-CM-2015-0029.

\section{Literature Cited}

Alvarado-Serrano, D. F., L. LunA, And L. L. Knowles. 2013. Localized versus generalist phenotypes in a broadly distributed tropical mammal: how is intraspecific variation distributed across disparate environments? BMC Evolutionary Biology 13:160.

Amador, L. I., R. L. M. Arévalo, F. C. Almeida, S. A. Catalano, and N. P. GIANNINI. In press. Bat systematics in the light of unconstrained analyses of a comprehensive molecular supermatrix. Journal of Mammalian Evolution.

Armstrong, G. D., And A. Macey. 1979. Proposals for a Sangay National Park in Ecuador. Biological Conservation 16:43-61.

Bensasson, D., D.-X. Zhang, D. L. Hartl and G. M. Hewitt. 2001. Mitochondrial pseudogenes: evolution's misplaced witnesses. Trends in Ecology \& Evolution 16:314-321.

Bernal, X. E., and C. M. Pinto. 2016. Sexual differences in prevalence of a new species of trypanosome infecting túngara frogs. International Journal for Parasitology: Parasites and Wildlife 5:40-47.

Borisenko, A. V., B. K. Lim, N. V. Ivanova, R. H. Hanner, and P. D. N. HeBert. 2008. DNA barcoding in surveys of small mammal communities: a field study in Suriname. Molecular Ecology Resources 8:471-479.

BRito, J., ANd R. OJala-Barbour. 2014. Presencia de la rata invasora Rattus rattus (Rodentia: Muridae) en el Parque Nacional Sangay, Ecuador. Therya 5:323-329.

Brito, J., H. Orellana, and G. Tenecota. 2014. Descripción del nido de Hylaeamys yunganus (Rodentia: Cricetidae) de los Andes del sureste de Ecuador. Avances en Ciencias e Ingenierías 6:B10-B12.

Brito, J., N. Tinoco, AND F. Zornoza. 2015. Nuevo registro distribucional del ratón endémico Nephelomys nimbosus (Rodentia: Cricetidae) en el suroriente de Ecuador. Therya 6:667-674.

Brito, J. M., N. Tinoco, D. Chávez, P. Moreno-Cárdenas, D. Batallas, and R. Ojala-Barbour. 2017. New species of arboreal rat of the genus Rhipidomys (Cricetidae, Sigmodontinae) from Sangay National Park, Ecuador. Neotropical Biodiversity 3:65-79.

Carleton, M. D., ANd G. G. Musser. 1989. Systematic studies of oryzomyine rodents (Muridae, Sigmodontinae): a synopsis of Microryzomys. Bulletin of the American Museum of Natural History 191:1-83.

Carstens, B. C., T. A. Pelletier, N. M. Reid, and J. D. Satler. 2013. How to fail at species delimitation. Molecular Ecology 22:4369-4383.

Clare, E. L., B. K. Lim, M. D. Engstrom, J. L. Eger, and P. D. N. Hebert. 2007. DNA barcoding of Neotropical bats: species identification and discovery within Guyana. Molecular Ecology Notes 7:184-190.

CottontalL, V. M. et Al. 2014. High local diversity of Trypanosoma in a common bat species, and implications for the biogeography and taxonomy of the T. cruzi clade. PLoS ONE 9:e108603. 
EdGAR, R. C. 2004. MUSCLE: multiple sequence alignment with high accuracy and high throughput. Nucleic Acids Research 32:1792-1797.

Eldredge, N., And Cracraft, J. 1980. Phylogenetic patterns and the evolutionary process: methods and theory in comparative biology. Columbia University Press, New York.

ERMAKOV, O. A. ET AL. 2015. Implications of hybridization, NUMTs, and overlooked diversity for DNA barcoding of Eurasian ground squirrels. PLOS ONE 10:e0117201.

Foley, N. M., M. S. Springer, and E. C. Teeling. 2016. Mammal madness: is the mammal tree of life not yet resolved? Philosophical Transactions of the Royal Society B 371:20150140.

FonsecA, R. M. ET AL. 2003. Identificación preliminar de un corredor ecológico para mamíferos entre los parques nacionales Llanganates y Sangay. Revista de la Pontificia Universidad Católica del Ecuador 71:201-216.

González-Ittig, R. E., P. C. Rivera, S. C. Levis, G. E. Calderón, and C. N. GaRdenAL. 2014. The molecular phylogenetics of the genus Oligoryzomys (Rodentia: Cricetidae) clarifies rodent hosthantavirus associations: Rodent Host-Hantavirus genotype relationships. Zoological Journal of the Linnean Society 171:457-474.

HarRIS, S. E., AND M. Bellino. 2013. DNA barcoding from NYC to Belize. Science 342:1462-1463.

Hebert, P. D. N., A. Cywinska, S. L. Ball, and J. R. deWaArd. 2003. Biological identifications through DNA barcodes. Proceedings of the Royal Society of London B: Biological Sciences 270:313-321.

Hebert, P. D. N., and T. R. Gregory. 2005. The promise of DNA barcoding for taxonomy. Systematic biology 54:852-859.

Helgen, K. M. et AL. 2009. Taxonomic boundaries and geographic distributions revealed by an integrative systematic overview of the mountain coatis, Nasuella (Carnivora: Procyonidae). Small Carnivore Conservation 41:65-74.

Helgen, K. M. et al. 2013. Taxonomic revision of the olingos (Bassaricyon), with description of a new species, the Olinguito. ZooKeys 324:1-83.

Hughes, C., AND R. EAstwood. 2006. Island radiation on a continental scale: Exceptional rates of plant diversification after uplift of the Andes. Proceedings of the National Academy of Sciences 103:10334-10339.

JARRín, P. 2001. Mamíferos en la niebla Otonga, un bosque nublado del Ecuador. Museo de Zoología, Centro de Biodiversidad y Ambiente, Pontificia Universidad Católica del Ecuador, Quito.

Lee, T. E., C. Boada-Terán, A. M. Scott, S. F. Burneo, and J. D. Hanson. 2011. Small mammals of Sangay National Park, Chimborazo Province and Morona Santiago Province, Ecuador. Occasional Papers Museum of Texas Tech University 305:1-16.

Lee, T. E., A. R. Ritchie, S. Vaca-Puente, J. M. Brokaw, M. A. Camacho, AND S. F. Burneo. 2015. Small mammals of Guandera Biological Reserve, Carchi Province, Ecuador and comparative Andean small mammal ecology. Occasional Papers Museum of Texas Tech University 334:1-20.

Maestri, R., And B. D. Patterson. 2016. Patterns of species richness and turnover for the South American rodent fauna. PLOS ONE 11:e0151895.
Meredith, R. W., J. E. JaneČKA, J. Gatesy, O. A. Ryder, C. A. Fisher, E. C. Teeling, A. Goodbla, E. EIzIRIK, T. L. Simão, T. Stadler, and D. L Rabosky. 2011. Impacts of the Cretaceous terrestrial revolution and $\mathrm{KPg}$ extinction on mammal diversification. Science 334:521-524. Messing, J. 1983. New M13 vectors for cloning. Methods in Enzymology 101:20-78.

Monasterio, M., and L. Sarmiento. 1991. Adaptive radiation of Espeletia in the cold Andean tropics. Trends in Ecology \& Evolution 6:387-391.

MüLLER, L. ET AL. 2013. DNA barcoding of sigmodontine rodents: identifying wildlife reservoirs of zoonoses. PLoS ONE 8:e80282. Myers, N., R. A. Mittermeier, C. G. Mittermeier, G. A. B. da Fonseca, AND J. KENT. 2000. Biodiversity hotspots for conservation priorities. Nature 403:853-858.

Nicolas, V.et AL. 2012. Assessment of three mitochondrial genes (16S, Cytb, CO1) for identifying species in the Praomyini tribe (Rodentia: Muridae). PLoS ONE 7:e36586.

Nürk, N. M., C. Scheriau, AND S. Madriñán. 2013. Explosive radiation in high Andean Hypericum - rates of diversification among New World lineages. Frontiers in genetics 4:175.

Ojala-Barbour, R., C. M. Pinto, J. Brito, L. Albuja, T. E. Lee, and B. D. Patterson. 2013. A new species of shrew-opossum (Paucituberculata: Caenolestidae) with a phylogeny of extant caenolestids. Journal of Mammalogy 94:967-982.

PACHECO, V. 2003. Phylogenetic analyses of the Thomasomyini (Muroidea: Sigmodontinae) based on morphological data. City University of New York.

PacheCo, V. 2015. Genus Thomasomys Coues, 1884. Pp. 617-682 in Mammals of South America (Patton, J. L., U. F. J. Pardiñas, and G. D'Elía, eds.). The University of Chicago Press. Chicago \& London.

Patterson, B. D. 2002. On the continuing need for scientific collecting of mammals. Mastozoología Neotropical 9:253-262.

Patton, J. L., M. N. F. Da Silva, And J. R. Malcolm. 1994. Gene genealogy and differentiation among arboreal spiny rats (Rodentia: Echimyidae) of the Amazon basin: A test of the riverine barrier hypothesis. Evolution 48:1314-1323.

Patton, J. L., M. N. F. Da Silva, And J. R. Malcolm. 2000. Mammals of the Rio Juruá and the evolutionary and ecological diversification of Amazonia. Bulletin of the American Museum of Natural History 244:1-306.

Patton, J. L., U. F. J. PARDiÑAS, AND G. D'Elía (eds.). 2015. Mammals of South America, Volume 2: Rodents. The University of Chicago Press. Chicago and London.

Percequillo, A. R. 2003. Sistemática de Oryzomys Baird, 1858: definição dos grupos de espécies e revisão taxonômica do grupo albigularis (Rodentia, Sigmodontinae). Universidade de São Paulo.

Percequillo, A. R. 2015. Genus Nephelomys Weksler, Percequillo, and Voss, 2006. Pp. 377-390 in Mammals of South America (Patton, J. L. , U. F. J. Pardiñas, and G. D’Elía, eds.). The University of Chicago Press. Chicago \& London.

Pinto, C. M. ET AL. 2016. Archaeology, biogeography, and mammalogy do not provide evidence for tarukas (Cervidae: Hippocamelus antisensis) in Ecuador. Journal of Mammalogy 97:41-53.

Pons, J. ET AL. 2006. Sequence-based species delimitation for the DNA taxonomy of undescribed insects. Systematic Biology 55:595-609. 
Prado, J. R. et Al. 2015. Species richness and areas of endemism of oryzomyine rodents (Cricetidae, Sigmodontinae) in South America: an ndm/vndm approach. Journal of Biogeography 42:540-551.

StAmATAKIS, A. 2014. RAxML version 8: a tool for phylogenetic analysis and post-analysis of large phylogenies. Bioinformatics 30:1312-1313.

Salazar-Bravo, J. , and T. L. Yates. 2007. A new species of Thomasomys (Cricetidae: Sigmodontinae) from central Bolivia. Pp. 747-774 in The Quintessential Naturalist: Honoring the Life and Legacy of Oliver P. Pearson. (Kelt, D. A., E. P. Lessa, J. Salazar-Bravo, and J. L. Patton, eds.). University of California Publications in Zoology 134:1-981.

Salazar-Bravo, J. , U. F. J. Pardiñas, H. Zeballos, , and P. Teta. 2016. Description of a new tribe of sigmodontine rodents (Cricetidae: Sigmodontinae) with updated summary of valid tribes and their generic contents. Occassional Papers Museum of Texas Tech University 338:1-24.

Tang, C. Q., A. M. Humphreys, D. Fontaneto, and T. G. Barraclough. 2014. Effects of phylogenetic reconstruction method on the robustness of species delimitation using single-locus data. Methods in Ecology and Evolution 5:1086-1094.

Tinoco LóPEZ, N. O. 2015. Caracterización molecular, morfológica y morfometrica del complejo Nephelomys albigularis Tomes, 1860 (Rodentia: Cricetidae), y su distribución en el Ecuador. Pontificia Universidad Católica del Ecuador.

Tobe, S. S., A. C. Kitchener, AND A. M. T. Linacre. 2010. Reconstructing mammalian phylogenies: a detailed comparison of the cytochrome $b$ and cytochrome oxidase subunit I mitochondrial genes. PLoS ONE 5:e14156.

Upham, N. S., R. Ojala-Barbour, J. Brito M, P. M. Velazco, and B. D. PATTERSON. 2013. Transitions between Andean and Amazonian centers of endemism in the radiation of some arboreal rodents. BMC Evolutionary Biology 13:191.

Voss, R. S. 2003. A new species of Thomasomys (Rodentia: Muridae) from eastern Ecuador, with remarks on mammalian diversity and biogeography in the Cordillera Oriental. American Museum Novitates 3421:1-47.

Voss, R. S. 2009. Review of: Mammals of South America. Volume 1: Marsupials, xenarthrans, shrews, and bats (Gardner A. L., ed.). Journal of Mammalogy 90:521-523.

WeKsLER, M. 2006. Phylogenetic relationships of oryzomine rodents (Muroidea: Sigmodontinae): separate and combined analyses of morphological and molecular data. Bulletin of the American Museum of Natural History 296:1-149.

WeKsler, M., AND C. R. Bonvicino. 2005. Taxonomy of pigmy rice rats genus Oligoryzomys Bangs, 1900 (Rodentia, Sigmodontinae) of the Brazilian Cerrado, with the description of two new species. Arquivos do Museu Nacional 63:113-130.

WeKsler, M., AND C. R. Bonvicino. 2015. Genus Oligoryzomys Bangs, 1900. Pp. 417-437 in Mammals of South America (Patton, J. L., U. F. J. Pardiñas, and G. D'Elía, eds.). The University of Chicago Press. Chicago \& London.

Weksler, M., E. M. Lemos, P. S. D'Andrea, And C. R. Bonvicino. 2017. The taxonomic status of Oligoryzomys mattogrossae (Allen 1916) (Rodentia: Cricetidae: Sigmodontinae), reservoir of Anajatuba Hantavirus. American Museum Novitates 3880:1-32.

Weksler, M., A. R. Percequillo, and R. S. Voss. 2006. Ten new genera of oryzomyine rodents (Cricetidae: Sigmodontinae). American Museum Novitates 3537:1-29.

Zhang, J., P. Kapli, P. Pavlidis, and A. Stamatakis. 2013. A general species delimitation method with applications to phylogenetic placements. Bioinformatics 29:2869-2876.

Zwickl, D. J., AND D. M. Hillis. 2002. Increased taxon sampling greatly reduces phylogenetic error. Systematic Biology 51:588-598.

Associated editor: Guillermo D'Elia

Submitted: Julio 15, 2016; Reviewed: December 13, 2017;

Accepted:September 13, 2017; Published on line: January 15, 2018.

\section{Appendix}

List of the 201 samples of mammals from Otonga Reserve and Sangay National Park sequenced for this study. List includes collector numbers, museum numbers, collection locality, and GenBank accession numbers.

\begin{tabular}{llllll}
\hline Species & Field number & Tissue number & Museum number & Locality & GenBank Accession \\
\hline Akodon mollis A & PS14 & -- & FMNH 219797 & Sangay & MF806219 \\
Akodon mollis A & PS4 & -- & FMNH 219798 & Sangay & MF806236 \\
Akodon mollis A & PS17 & -- & FMNH 219804 & Sangay & MF806257 \\
Akodon mollis A & PS26 & -- & FMNH 219805 & Sangay & MF806260 \\
Akodon mollis A & PS6 & -- & MEPN 12135 & Sangay & MF806212 \\
Akodon mollis A & PS10 & -- & MEPN 12138 & Sangay & MF806220 \\
Akodon mollis A & PS34 & -- & MEPN 12156 & Sangay & MF806223 \\
Akodon mollis A & PS39 & -- & MEPN 12161 & Sangay & MF806238 \\
Akodon mollis A & TEL2235 & ACUNHC1618 & QCAZ 11880 & Sangay & MF806242 \\
Akodon mollis A & TEL2242 & -- & QCAZ 11881 & Sangay & MF806261 \\
Akodon mollis A & TEL2256 & ACUNHC1595 & QCAZ 11882 & Sangay & MF806234 \\
Akodon mollis A & TEL2257 & ACUNHC1586 & QCAZ 11883 & Sangay & MF806226 \\
Akodon mollis A & TEL2321 & ACUNHC1583 & QCAZ 11884 & Sangay & MF806254 \\
Akodon mollis A & TEL2328 & ACUNHC1585 & QCAZ 11885 & Sangay & MF806256 \\
Akodon mollis A & TEL2346 & -- & QCAZ 11888 & Sangay & MF806252
\end{tabular}




\begin{tabular}{|c|c|c|c|c|c|}
\hline Akodon mollis A & TEL2363 & -- & QCAZ 11889 & Sangay & MF806240 \\
\hline Akodon mollis A & TEL2237 & ACUNHC1587 & QCAZ 11890 & Sangay & MF806245 \\
\hline Akodon mollis A & TEL2238 & ACUNHC1575 & QCAZ 11891 & Sangay & MF806239 \\
\hline Akodon mollis A & TEL2240 & ACUNHC1620 & QCAZ 11892 & Sangay & MF806248 \\
\hline Akodon mollis A & TEL2253 & ACUNHC1619 & QCAZ 11893 & Sangay & MF806224 \\
\hline Akodon mollis A & TEL2259 & -- & QCAZ 11894 & Sangay & MF806225 \\
\hline Akodon mollis A & TEL2268 & -- & QCAZ 11895 & Sangay & MF806216 \\
\hline Akodon mollis A & TEL2269 & ACUNHC1603 & QCAZ 11896 & Sangay & MF806235 \\
\hline Akodon mollis A & TEL2272 & ACUNHC1616 & QCAZ 11897 & Sangay & MF806221 \\
\hline Akodon mollis A & TEL2273 & ACUNHC1604 & QCAZ 11898 & Sangay & MF806217 \\
\hline Akodon mollis A & TEL2276 & ACUNHC1628 & QCAZ 11899 & Sangay & MF806262 \\
\hline Akodon mollis A & TEL2277 & ACUNHC1577 & QCAZ 11900 & Sangay & MF806258 \\
\hline Akodon mollis A & TEL2280 & ACUNHC1579 & QCAZ 11901 & Sangay & MF806222 \\
\hline Akodon mollis A & TEL2281 & -- & QCAZ 11902 & Sangay & MF806218 \\
\hline Akodon mollis A & TEL2282 & ACUNHC1584 & QCAZ 11903 & Sangay & MF806237 \\
\hline Akodon mollis A & TEL2286 & -- & QCAZ 11904 & Sangay & MF806249 \\
\hline Akodon mollis A & TEL2289 & -- & QCAZ 11905 & Sangay & MF806263 \\
\hline Akodon mollis A & TEL2297 & ACUNHC1591 & QCAZ 11906 & Sangay & MF806227 \\
\hline Akodon mollis A & TEL2299 & -- & QCAZ 11907 & Sangay & MF806255 \\
\hline Akodon mollis A & TEL2302 & -- & QCAZ 11908 & Sangay & MF806228 \\
\hline Akodon mollis A & TEL2314 & ACUNHC1576 & QCAZ 11910 & Sangay & MF806229 \\
\hline Akodon mollis A & TEL2317 & ACUNHC1596 & QCAZ 11911 & Sangay & MF806230 \\
\hline Akodon mollis A & TEL2350 & -- & QCAZ 11913 & Sangay & MF806259 \\
\hline Akodon mollis A & TEL2352 & -- & QCAZ 11914 & Sangay & MF806253 \\
\hline Akodon mollis A & TEL2356 & -- & QCAZ 11915 & Sangay & MF806243 \\
\hline Akodon mollis A & TEL2370 & ACUNHC1581 & QCAZ 11916 & Sangay & MF806250 \\
\hline Akodon mollis A & TEL2376 & -- & QCAZ 11917 & Sangay & MF806241 \\
\hline Akodon mollis A & TEL2379 & -- & QCAZ 11918 & Sangay & MF806246 \\
\hline Akodon mollis A & TEL2385 & -- & QCAZ 11919 & Sangay & MF806244 \\
\hline Akodon mollis A & TEL2389 & ACUNHC1580 & QCAZ 11920 & Sangay & MF806247 \\
\hline Akodon mollis A & TEL2390 & -- & QCAZ 11921 & Sangay & MF806214 \\
\hline Akodon mollis A & TEL2391 & -- & QCAZ 11922 & Sangay & MF806231 \\
\hline Akodon mollis A & TEL2392 & -- & QCAZ 11923 & Sangay & MF806213 \\
\hline Akodon mollis A & TEL2396 & -- & QCAZ 11924 & Sangay & MF806232 \\
\hline Akodon mollis A & TEL2397 & -- & QCAZ 11925 & Sangay & MF806215 \\
\hline Akodon mollis A & TEL2399 & -- & QCAZ 11926 & Sangay & MF806211 \\
\hline Akodon mollis A & TEL2400 & -- & QCAZ 11927 & Sangay & MF806251 \\
\hline Akodon mollis A & TEL2401 & -- & QCAZ 11928 & Sangay & MF806233 \\
\hline Akodon mollis B & KMH2227 & TK149044 & QCAZ 8634 & Otonga & MF806209 \\
\hline Akodon mollis B & MP74 & TK149070 & QCAZ 8635 & Otonga & MF806210 \\
\hline Chilomys instans A & PS24 & -- & MEPN 12149 & Sangay & MF806264 \\
\hline Chilomys instans B & MP62 & TK149051 & QCAZ 8691 & Otonga & MF806266 \\
\hline Chilomys instans B & MP64 & TK149053 & QCAZ 8693 & Otonga & MF806269 \\
\hline Chilomys instans B & MP69 & TK149058 & QCAZ 8694 & Otonga & MF806265 \\
\hline Chilomys instans B & MP91 & TK149099 & QCAZ 8695 & Otonga & MF806267 \\
\hline Chilomys instans B & KMH2241 & TK149080 & QCAZ 8740 & Otonga & MF806268 \\
\hline Hylaeamys tatei & PS22 & -- & MEPN 12147 & Sangay & MF806196 \\
\hline Mesomys hispidus & JBM368 & -- & MEPN 12212 & Kutukú & MF806172 \\
\hline Microryzomys altissimus & TEL2298 & -- & QCAZ 11929 & Sangay & MF806185 \\
\hline Microryzomys altissimus & TEL2347 & ACUNHC1553 & QCAZ 11930 & Sangay & MF806183 \\
\hline Microryzomys altissimus & TEL2278 & ACUNHC1605 & QCAZ 11931 & Sangay & MF806182 \\
\hline Microryzomys altissimus & TEL2279 & -- & QCAZ 11932 & Sangay & MF806179 \\
\hline Microryzomys altissimus & TEL2322 & -- & QCAZ 11933 & Sangay & MF806181 \\
\hline
\end{tabular}


Microryzomys altissimus

Microryzomys altissimus

Microryzomys minutus

Microryzomys minutus

Microryzomys minutus

Microryzomys minutus

Microryzomys minutus

Microryzomys minutus

Microryzomys minutus

Microryzomys minutus

Microryzomys minutus

Microryzomys minutus

Mindomys sp.

Nephelomys moerex

Nephelomys moerex

Nephelomys moerex

Nephelomys moerex

Nephelomys moerex

Nephelomys moerex

Nephelomys moerex

Nephelomys sp. A

Nephelomys sp. B

Oligoryzomys spodiurus

Oligoryzomys spodiurus

Oreoryzomys balneator

Oreoryzomys balneator

Oreoryzomys balneator

Oreoryzomys balneator

Rhipidomys albujai

Rhipidomys sp.

Thomasomys baeops

Thomasomys baeops

Thomasomys baeops

Thomasomys caudivarius

Thomasomys caudivarius

Thomasomys caudivarius

Thomasomys caudivarius

Thomasomys caudivarius

Thomasomys caudivarius

Thomasomys caudivarius

Thomasomys caudivarius

Thomasomys caudivarius

Thomasomys caudivarius

Thomasomys caudivarius

Thomasomys caudivarius

Thomasomys caudivarius

Thomasomys caudivarius

Thomasomys caudivarius

Thomasomys caudivarius

Thomasomys caudivarius

Thomasomys caudivarius

Thomasomys caudivarius

Thomasomys caudivarius
TEL2327

TEL2258

KMH2235

KMH2236

KMH2257

KMH2258

MP53

PS9

PS35

PS69

TEL2362

TEL2371

MP88

KMH2204

$\mathrm{KMH} 2210$

KMH2221

$\mathrm{KMH} 2253$

MP83

MP90

MP93

PS2

PS3

MP75

MP85

--

PS66

PS57

PS56

PS75

$-$

MP92

KMH2225

KMH2209

PS28

PS29

PS36

TEL2345

TEL2270

TEL2271

TEL2285

TEL2287

TEL2293

TEL2301

TEL2318

TEL2319

TEL2343

TEL2344

TEL2354

TEL2355

TEL2377

TEL2393

TEL2398

TEL2402
$-$

--

TK149063

TK149064

TK149106

TK149107

TK149026

--

$-$

$--$

ACUNHC1556

ACUNHC1571

TK149096

TK149005

TK149009

TK149038

TK149102

TK149079

TK149098

TK149101

--

$--$

TK149071

TK149093

--

$--$

$-$

$-$

$-$

--

TK149100

TK149042

TK149010

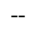

$-$

$--$

ACUNHC1602

ACUNHC1572

ACUNHC1592

ACUNHC1563

--

ACUNHC1557

ACUNHC1562

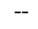

$--$

ACUNHC1567

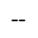

ACUNHC1554

ACUNHC1573

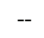

$-$

$-$

$-$
QCAZ 11934

QCAZ 11973

Sangay

MF806180

QCAZ 8673

Sangay

MF806184

Otonga

MF806186

QCAZ 8674

Otonga

MF806187

QCAZ 8675

Otonga

MF806189

QCAZ 8676

Otonga

MF806188

QCAZ 8677

Otonga

MF806195

FMNH 219796

Sangay

MF806194

MEPN 12158

Sangay

MF806191

MEPN 12190

Sangay

MF806190

MF806193

MF806192

MF806197

MF806204

MF806198

MF806201

MF806202

MF806203

MF806200

MF806199

MF806205

MF806206

MF806174

MF806173

QCAZ 8681

MEPN 12226

MEPN 12187

MEPN 12189

MEPN 12197

MEPN 12196

MEPN 12114

QCAZ 8746

QCAZ 8692

QCAZ 8739

MEPN 12151

MEPN 12152

MEPN 12159

QCAZ 11912

OCAZ 11949

QCAZ 11950

QCAZ 11951

QCAZ 11952

QCAZ 11953

QCAZ 11954

QCAZ 11955

QCAZ 11956

QCAZ 11959

QCAZ 11960

QCAZ 11961

QCAZ 11962

QCAZ 11964

QCAZ 11965

QCAZ 11966

QCAZ 11967
Sangay

Sangay

Otonga

Otonga

Cordillera del Cóndor

MF806175

Sangay

Sangay

Sangay

Sangay

Cordillera del Cóndor

Otonga

Otonga

Otonga

Sangay

Sangay

Sangay

Sangay

Sangay

Sangay

Sangay

Sangay

Sangay

Sangay

Sangay

Sangay

Sangay

Sangay

Sangay

Sangay

Sangay

Sangay

Sangay

Sangay

MF806311
MF806178

MF806177

MF806176

MF806208

MF806207

MF806276

MF806275

MF806274

MF806307

MF806323

MF806309

MF806325

MF806310

MF806312

MF806313

MF806314

MF806322

MF806315

MF806316 


\begin{tabular}{|c|c|c|c|c|c|}
\hline Thomasomys cinnameus & PS40 & -- & MEPN 12163 & Sangay & MF806291 \\
\hline Thomasomys cinnameus & TEL2236 & ACUNHC1601 & QCAZ 11968 & Sangay & MF806299 \\
\hline Thomasomys cinnameus & TEL2243 & ACUNHC1564 & QCAZ 11969 & Sangay & MF806293 \\
\hline Thomasomys cinnameus & TEL2246 & -- & QCAZ 11970 & Sangay & MF806298 \\
\hline Thomasomys cinnameus & TEL2250 & -- & QCAZ 11971 & Sangay & MF806297 \\
\hline Thomasomys cinnameus & TEL2252 & -- & QCAZ 11972 & Sangay & MF806292 \\
\hline Thomasomys cinnameus & TEL2291 & ACUNHC1559 & QCAZ 11975 & Sangay & MF806303 \\
\hline Thomasomys cinnameus & TEL2292 & ACUNHC1627 & QCAZ 11976 & Sangay & MF806300 \\
\hline Thomasomys cinnameus & TEL2296 & ACUNHC1610 & QCAZ 11977 & Sangay & MF806301 \\
\hline Thomasomys cinnameus & TEL2307 & ACUNHC1611 & QCAZ 11978 & Sangay & MF806295 \\
\hline Thomasomys cinnameus & TEL2308 & -- & QCAZ 11979 & Sangay & MF806294 \\
\hline Thomasomys cinnameus & TEL2310 & ACUNHC1582 & QCAZ 11980 & Sangay & MF806305 \\
\hline Thomasomys cinnameus & TEL2311 & -- & QCAZ 11981 & Sangay & MF806302 \\
\hline Thomasomys cinnameus & TEL2329 & -- & QCAZ 11982 & Sangay & MF806306 \\
\hline Thomasomys cinnameus & TEL2274 & -- & QCAZ 11983 & Sangay & MF806296 \\
\hline Thomasomys cinnameus & TEL2365 & -- & QCAZ 12018 & Sangay & MF806337 \\
\hline Thomasomys paramorum & TEL2233 & ACUNHC1624 & QCAZ 11984 & Sangay & MF806359 \\
\hline Thomasomys paramorum & TEL2234 & ACUNHC1593 & QCAZ 11985 & Sangay & MF806360 \\
\hline Thomasomys paramorum & TEL2239 & ACUNHC1626 & QCAZ 11986 & Sangay & MF806361 \\
\hline Thomasomys paramorum & TEL2241 & ACUNHC1590 & QCAZ 11987 & Sangay & MF806362 \\
\hline Thomasomys paramorum & TEL2244 & ACUNHC1600 & QCAZ 11988 & Sangay & MF806358 \\
\hline Thomasomys paramorum & TEL2245 & ACUNHC1625 & QCAZ 11989 & Sangay & MF806357 \\
\hline Thomasomys paramorum & TEL2247 & ACUNHC1597 & QCAZ 11990 & Sangay & MF806329 \\
\hline Thomasomys paramorum & TEL2248 & ACUNHC1574 & QCAZ 11991 & Sangay & MF806363 \\
\hline Thomasomys paramorum & TEL2249 & ACUNHC1607 & QCAZ 11992 & Sangay & MF806364 \\
\hline Thomasomys paramorum & TEL2251 & ACUNHC1589 & QCAZ 11993 & Sangay & MF806356 \\
\hline Thomasomys paramorum & TEL2255 & ACUNHC1612 & QCAZ 11994 & Sangay & MF806334 \\
\hline Thomasomys paramorum & TEL2262 & ACUNHC1599 & QCAZ 11996 & Sangay & MF806333 \\
\hline Thomasomys paramorum & TEL2263 & ACUNHC1606 & QCAZ 11997 & Sangay & MF806354 \\
\hline Thomasomys paramorum & TEL2264 & ACUNHC1608 & QCAZ 11998 & Sangay & MF806353 \\
\hline Thomasomys paramorum & TEL2300 & ACUNHC1615 & QCAZ 11999 & Sangay & MF806352 \\
\hline Thomasomys paramorum & TEL2309 & ACUNHC1569 & QCAZ 12000 & Sangay & MF806340 \\
\hline Thomasomys paramorum & TEL2312 & ACUNHC1622 & QCAZ 12001 & Sangay & MF806327 \\
\hline Thomasomys paramorum & TEL2320 & -- & QCAZ 12002 & Sangay & MF806355 \\
\hline Thomasomys paramorum & TEL2323 & ACUNHC1568 & QCAZ 12003 & Sangay & MF806335 \\
\hline Thomasomys paramorum & TEL2324 & -- & QCAZ 12004 & Sangay & MF806330 \\
\hline Thomasomys paramorum & TEL2325 & ACUNHC1613 & QCAZ 12005 & Sangay & MF806304 \\
\hline Thomasomys paramorum & TEL2326 & -- & QCAZ 12006 & Sangay & MF806341 \\
\hline Thomasomys paramorum & TEL2348 & -- & QCAZ 12011 & Sangay & MF806338 \\
\hline Thomasomys paramorum & TEL2349 & ACUNHC1558 & QCAZ 12012 & Sangay & MF806346 \\
\hline Thomasomys paramorum & TEL2351 & -- & QCAZ 12013 & Sangay & MF806336 \\
\hline Thomasomys paramorum & TEL2353 & -- & QCAZ 12014 & Sangay & MF806344 \\
\hline Thomasomys paramorum & TEL2357 & -- & QCAZ 12015 & Sangay & MF806339 \\
\hline Thomasomys paramorum & TEL2358 & -- & QCAZ 12016 & Sangay & MF806342 \\
\hline Thomasomys paramorum & TEL2364 & -- & QCAZ 12017 & Sangay & MF806331 \\
\hline Thomasomys paramorum & TEL2366 & -- & QCAZ 12019 & Sangay & MF806347 \\
\hline Thomasomys paramorum & TEL2367 & -- & QCAZ 12020 & Sangay & MF806343 \\
\hline Thomasomys paramorum & TEL2368 & -- & QCAZ 12021 & Sangay & MF806366 \\
\hline Thomasomys paramorum & TEL2369 & -- & QCAZ 12022 & Sangay & MF806349 \\
\hline Thomasomys paramorum & TEL2374 & -- & QCAZ 12023 & Sangay & MF806332 \\
\hline Thomasomys paramorum & TEL2375 & -- & QCAZ 12024 & Sangay & MF806348 \\
\hline Thomasomys paramorum & TEL2380 & ACUNHC1549 & QCAZ 12025 & Sangay & MF806365 \\
\hline Thomasomys paramorum & TEL2381 & -- & QCAZ 12026 & Sangay & MF806345 \\
\hline
\end{tabular}




\begin{tabular}{|c|c|c|c|c|c|}
\hline Thomasomys paramorum & TEL2383 & -- & QCAZ 12027 & Sangay & MF806351 \\
\hline Thomasomys paramorum & TEL2384 & -- & QCAZ 12028 & Sangay & MF806350 \\
\hline Thomasomys paramorum & TEL2275 & ACUNHC1623 & QCAZ 12029 & Sangay & MF806328 \\
\hline Thomasomys princeps & TEL2288 & -- & QCAZ 11937 & Sangay & MF806271 \\
\hline Thomasomys princeps & TEL2295 & -- & QCAZ 11938 & Sangay & MF806273 \\
\hline Thomasomys princeps & TEL2378 & ACUNHC1560 & QCAZ 11939 & Sangay & MF806272 \\
\hline Thomasomys princeps & TEL2394 & ACUNHC1548 & QCAZ 11940 & Sangay & MF806270 \\
\hline Thomasomys silvestris & KMH2237 & TK149065 & QCAZ 8741 & Otonga & MF806371 \\
\hline Thomasomys silvestris & MP66 & TK149055 & QCAZ 8742 & Otonga & MF806367 \\
\hline Thomasomys silvestris & MP68 & TK149057 & QCAZ 8743 & Otonga & MF806369 \\
\hline Thomasomys silvestris & MP70 & TK149059 & QCAZ 8744 & Otonga & MF806372 \\
\hline Thomasomys silvestris & KMH2231 & TK149048 & QCAZ 8747 & Otonga & MF806370 \\
\hline Thomasomys silvestris & MP82 & TK149078 & QCAZ 8749 & Otonga & MF806368 \\
\hline Thomasomys taczanowskii A & PS56 & -- & FMNH 219801 & Sangay & MF806277 \\
\hline Thomasomys taczanowskii A & PS25 & -- & FMNH 219803 & Sangay & MF806278 \\
\hline Thomasomys taczanowskii B & -- & -- & MEPN 12224 & Cordillera del Cóndor & MF806282 \\
\hline Thomasomys taczanowskii B & PS1 & -- & MEPN 12132 & Sangay & MF806285 \\
\hline Thomasomys taczanowskii B & PS64 & -- & MEPN 12185 & Sangay & MF806281 \\
\hline Thomasomys taczanowskii B & TEL2254 & ACUNHC1598 & QCAZ 11941 & Sangay & MF806286 \\
\hline Thomasomys taczanowskii B & TEL2290 & ACUNHC1570 & QCAZ 11942 & Sangay & MF806287 \\
\hline Thomasomys taczanowskii B & TEL2306 & ACUNHC1614 & QCAZ 11943 & Sangay & MF806288 \\
\hline Thomasomys taczanowskii B & TEL2386 & -- & QCAZ 11945 & Sangay & MF806290 \\
\hline Thomasomys taczanowskii B & TEL2387 & -- & QCAZ 11946 & Sangay & MF806289 \\
\hline Thomasomys taczanowskii B & TEL2388 & -- & QCAZ 11947 & Sangay & MF806280 \\
\hline Thomasomys taczanowskii B & TEL2395 & -- & QCAZ 11948 & Sangay & MF806279 \\
\hline Thomasomys taczanowskii B & TEL2372 & -- & QCAZ 11963 & Sangay & MF806283 \\
\hline Thomasomys taczanowskii B & TEL2261 & ACUNHC1609 & QCAZ 11995 & Sangay & MF806284 \\
\hline
\end{tabular}


DNA BARCODES OF ANDEAN RODENTS

28 THERYA Vol. 9 (1): 15-27 